\title{
ALWQTISHADIYAH
}

Jurnal Ekonomi Syariah dan Hukum Ekonomi Syariah

E-ISSN: 2621-0274; P-ISSN: 2442-2282

Volume 5, Nomor 1, Juni 2019

\section{FAKTOR-FAKTOR YANG MEMPENGARUHI MINAT BELI PAKAIAN SYAR'I (STUDI KASUS MAHASISWI UIN ANTASARI BANJARMASIN)}

\author{
Eka Sri Apriliana \\ Fakultas Ekonomi dan Bisnis Islam, Universitas Islam Negeri Antasari, Indonesia. E-mail: \\ ekasriaprilliana2308@gmail.com
}

\section{ARTICLE INFO}

\section{Keywords:}

Buying Interest; Prices;

Religiosity; Syar'i

Clothing; Trends

Kata Kunci:

Harga; Minat Beli;

Religiusitas; Pakaian

Syar'i; Tren

\section{ABSTRACT}

This research analyzes factors that influence the buying interest of female students in sharia clothing, namely price, trends and religiosity. This research was conducted with a quantitative approach with the sampling technique used is proportional stratified sampling. The research data obtained were analyzed using the Multiple Liner Regression Analysis technique with the help of the SPSS version 22 program. This study produced findings: First: the independent variables in this study consisted of price (X1), trend (X2) and religiosity (X3) simultaneously influences the buying interest $(Y)$ of syar'i clothing for female students of UIN Antasari Banjarmasin with a Fcount value of 67.900 greater than the Ftable value of 1.19 (67.900> 1.19) and $a$ significant $F$ value of 0.000 less than an $\alpha$ value of $0,05(0,000<0.05)$ while partially each of the three variables, namely the price variable (X1), trend (X2) and religiosity (X3) affect the interest in buying sharia clothes in UIN Antasari Banjarmasin students. Second: religiosity is the most dominant variable partially influencing the buying interest of shari'a clothing for students of UIN Antasari Banjarmasin in accordance with the $t$ test, this is evidenced from the unstandardized coefficients of 0.467 and standardized coefficients of 0.503 and a sig level of 0.000 .

\section{ABSTRAK}

Penelitian ini menganalisa faktor yang mempengaruhi minat beli mahasiswi dalam berpakaian syar'i yaitu harga, tren dan religiusitas. Penelitian ini dilakukan dengan pendekatan kuantitatif dengan teknik pengambilan sampel yang digunakan yaitu Stratified Sampling Proporsional. Data penelitian yang diperoleh dianalisis menggunakan teknik Analisis Regresi Liner Berganda dengan bantuan program SPSS versi 22. Penelitian ini menghasilkan temuan-temuan: Pertama: variabel bebas dalam penelitian ini terdiri dari harga $\left(X_{1}\right)$, tren $\left(X_{2}\right)$ dan religiusitas $\left(\mathrm{X}_{3}\right)$ secara simultan bepengaruh terhadap minat beli $(\mathrm{Y})$ pakaian syar'i pada mahasiswi UIN Antasari Banjarmasin dengan nilai Fhitung sebesar 67,900 lebih besar dari nilai $F_{\text {tabel }}$ sebesar 1,19 (67,900 > $1,19)$ dan nilai signifikan $F$ sebesar 0,000 lebih kecil dari nilai $\alpha$ sebesar $0,05(0,000<0,05)$ sedangkan secara parsial masing-masing dari ketiga variabel tersebut yaitu variabel harga $\left(X_{1}\right)$, tren $\left(X_{2}\right)$ dan religiusitas $\left(X_{3}\right)$ berpengaruh terhadap minat beli pakaian syar'i pada mahasiswi UIN Antasari Banjarmasin. Kedua: religiusitas menjadi variabel yang paling dominan memberikan pengaruh secara parsial terhadap minat beli pakaian syar'i pada mahasiswi UIN Antasari Banjarmasin sesuai dengan 
uji t hal ini dibuktikan dari angka unstandardized coefficients sebesar 0,467 serta standardized coefficients sebesar 0,503 serta taraf sig sebesar 0,000 .

\section{Pendahuluan}

Berpakaian syar'i merupakan wujud ketaatan kepada Allah dan menjalankan perintah agama Islam. ${ }^{1}$ Pakaian syar'i dipakai untuk menutup aurat seorang wanita muslim. Adapun yang boleh melihat aurat seorang wanita muslim adalah mereka yang masih mempunyai hubungan darah yang haram dinikahi atau disebut mahram. Aurat wanita wajib ditutup sebagaimana perintah Allah kecuali pada orang-orang tertentu, sebagaimana Allah berfirman dalam Q.S An-Nur / 24: 31 sebagai berikut:

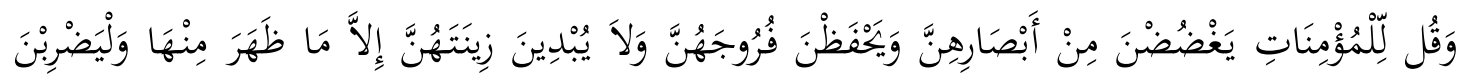

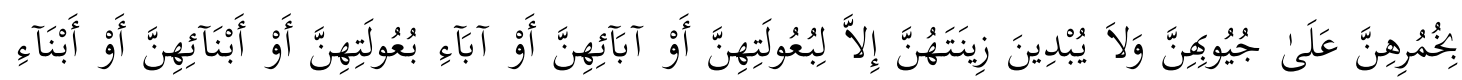

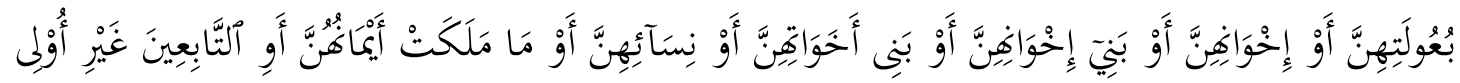

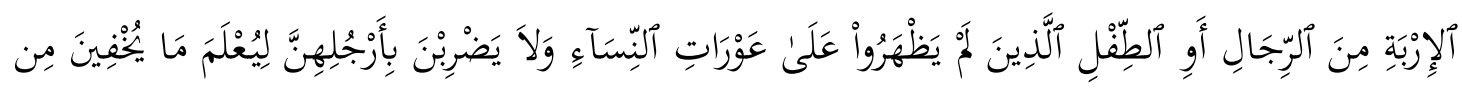

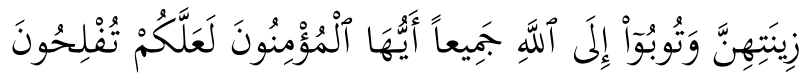

Artinya: "Katakanlah kepada wanita yang beriman: "Hendaklah mereka menahan pandangannya, dan kemaluannya, dan janganlah mereka menampakkan perhiasannya, kecuali yang (biasa) nampak dari padanya. Dan hendaklah mereka menutupkan kain kudung kedadanya, dan janganlah menampakkan perhiasannya kecuali kepada suami mereka, atau ayah mereka, atau ayah suami mereka, atau putera-putera mereka, atau putera-putera suami mereka, atau saudara-saudara laki-laki mereka, atau putera-putera saudara lelaki mereka, atau putera-putera saudara perempuan mereka, atau wanita-wanita Islam, atau budak-budak yang mereka miliki, atau pelayan-pelayan laki-laki yang tidak mempunyai keinginan (terhadap wanita) atau anak-anak yang belum mengerti tentang aurat wanita. Dan janganlah mereka memukulkan kakinya agar diketahui perhiasan yang mereka sembunyikan. Dan bertaubatlah kamu sekalian kepada Allah, hai orang-orang yang beriman supaya kamu beruntung" 2

Dari surah tersebut terdapat batasan-batasan dalam penggunaan pakaian syar'i meliputi pakaian yang harus menutupi seluruh tubuh kecuali wajah dan telapak

\footnotetext{
${ }^{1}$ Istiqomah, “Motivasi Berjilbab Mahasiswa (Studi Kasus Pada Mahasiwa STAIN Salatiga Semester 1 Dan 7) (Skripsi tidak diterbitkan, Fakultas Tarbiyah Sekolah Tinggi Agama Islam Negeri (STAIN), Salatiga, 2013), hlm. 1.

${ }^{2}$ Yayasan Penyelenggaraan Penterjemah Al-Qur'an, Al-Qur'an ku Dengan Tajwid Blok Warna: 55 Masterpiece in 1 (Jakarta: Lestari Books, 2010), hlm. 246.
} 
tangan, tidak boleh dipakai untuk berhias dan tidak boleh kentat atau menampakkan lekuk tubuh dan tidak boleh menggunakan kain yang tipis atau tembus pandang. ${ }^{3}$

Perkembangan budaya dan teknologi yang senantiasa bergerak maju, mempengaruhi bentuk dan mode pakaian perempuan. Dan dalam perjalanan budaya dan teknologi manakala terjadi kemerdekaan kreativitas, para perancang mode sering menengok kebelakang, lalu mengadaptasi mode-mode masa silam dengan sentuhan-sentuhan populer dan berbagai macam improvisaasi. Pengulangan ini tentunya mengalami perubahan bentuk dan corak, serta tampil dengan peningkatan mutu. Sebab tidaklah mengherankan bila dalam perputaran mode busana sering kembali kepada bentuk-bentuk lampau. ${ }^{4}$ Dari sinilah pakaian syar'i hadir dengan mode-mode pakaian terbaru dan jenis yang bermacam-macam warna dan bentuk agar menarik para konsumen untuk membeli pakaian syar'i yang dipilih bukan lagi karena religiusitas tetapi bisa juga karna tren yang dibuat oleh para designer sehingga pencinta tren fashion pun berdatangan untuk memakai pakaian syar'i yang telah mengalami perubahan mulai dari zaman ke zaman.

Kita ketahui bahwa minat beli adalah keinginan seseorang yang mempengaruhi dalam membeli pakaian syar'i. Hal ini bisa dikarenakan beberapa faktor yaitu bisa karena faktor religiusitas, faktor tren, atau faktor harga dalam pembahasan diatas kita telah membahas tentang faktor religiusitas serta faktor tren, dan kemudian peneliti akan membahas minat seseorang dalam membeli pakaian syar'i yaitu karena faktor harga.

Harga adalah jumlah uang yang harus dibayar untuk satu unit barang atau jasa. Sebagai tambahan para ahli ekonomi sering kali mengartikan harga dalam pengertian yang luas untuk menunjukkan apa saja uang maupun barang yang harus dibayarkan. ${ }^{5}$ Dalam hal ini harga mempengaruhi minat beli seseorang dalam memilih pakaian syar'i. Karena sebagian besar masyarakat lebih memilih untuk melihat harganya baru beberapa faktor yang lainnya. Harga sangat erat kaitannya dengan permintan suatu barang. Dalam analisis ekonomi dianggap bahwa permintaan suatu barang dipengaruhi oleh tingkat harganya. Oleh karena itu dalam teori permintaan yang terutama dianalisis adalah hubungan antara jumlah permintaan suatu barang dengan harga barang tersebut. ${ }^{6}$

Hukum permintaan dijelaskan sifat hubungan antara permintaan suatu barang dengan tingkat harganya. Hukum permintaan pada hakikatnya merupakan suatu hipotesis yang menyatakan makin rendah harga suatu barang maka makin banyak permintaan terhadap barang tersebut. Sebaliknya makin tinggi harga barang tersebut maka makin sedikit permintaan terhadap barang tersebut. ${ }^{7}$ Maka hukum

\footnotetext{
${ }^{3}$ Abu Fathi Rabbani, The Secret of Hijab Stories (Surakarta: Ahad Books, 2014), hlm. 24.

${ }^{4}$ Ibid., hlm. 17.

${ }^{5}$ Sadono Sukirno, Pengantar Teori Makroekonomi (Jakarta, PT Raja Grafindo Persada, 1994), hlm 290.

${ }^{6}$ Sadono Sukirno, Mikroekonomi Teori Pengantar Edisi Ketiga (Jakarta: PT Raja Grafindo Persada), hlm.76.

${ }^{7}$ lbid.,
} 
permintaan tersebut berlaku juga untuk Mahasiswi UIN Antasari yang sekarang lagi maraknya menggunakan pakaian syar'i.

Kita ketahui mayoritas Mahasiswi UIN Antasari rata-rata bertempat tinggal di kost atau kontrakan yang lebih mahal pengeluaran dibandingkan yang bertempat tinggal di Banjarmasin. Kita bisa melihat fenomena sekarang yang maraknya Mahasiswi UIN Antasari Banjarmasin menggunakan pakaian syar'i.

Peneliti telah mensurvei bahwa harga pakaian syar'i bisa dikatakan mahal untuk Mahasiswi UIN Antasari, dalam wawancara pada pemilik toko penjual pakaian syar'i didapatkan data bahwa harga pakaian syar'i yang bermerek mencapai Rp 200.000Rp 722.000 sedangkan pakaian syar'i yang tidak bermerek mencapai harga Rp 275.000. ${ }^{8}$

Disimpulkan bahwa harga pakaian syar'i yang menggunakan merek ataupun tidak sama-sama mahal sekitar Rp 200.000- Rp 500.000. Melihat dari fenomena yang terjadi dikalangan Mahasiswi UIN Antasari Banjarmasin makin banyak minat dalam membeli dan memakai pakaian syar'i.

Observasi awal yang telah dilakukan oleh peneliti maka ditarik kesimpulan bahwa makin tinggi tingkat iman seseorang maka makin tinggi pula tingkat religiusitas sehingga penggunaan pakaian syar'i berpengaruh pada minat beli mahasiswi UIN Antasari. Ada 3 faktor yang mempengaruhi minat beli pakaian syar'i yaitu faktor religiusitas, tren dan harga.

Berdasarkan latar belakang di atas, maka didapat rumusan masalah yaitu:

1. Apakah harga, tren dan religiusitas berpengaruh secara simultan dan parsial terhadap minat beli pakaian syar'i pada mahasiswi UIN Antasari Banjarmasin?

2. Antara harga, tren dan religiusitas, variabel manakah yang paling dominan berpengaruh terhadap minat beli pakaian syar'i pada mahasiswi UIN Antasari Banjarmasin

\section{Landasan Teori}

\subsection{Perilaku Konsumen}

Perilaku konsumen adalah suatu disiplin ilmu yang mempelajari perilaku individu, kelompok, atau organisasi dan proses-proses yang digunakan konsumen untuk menyeleksi, menggunakan produk, pelayanan, pengalaman untuk memuaskan kebutuhan dan keinginan konsumen dan dampak dari proses-proses tersebut pada konsumen atau masyarakat. ${ }^{9}$

\footnotetext{
${ }^{8}$ Wawancara dengan Ibu Dianah (pemilik toko hijab syari dan gaul), tanggal 08.06.2017, di Pasar Kuripan.

${ }^{9}$ Etta Mamang Sangadji, Perilaku Konsumen (Yogyakarta: Andi, 2013), hlm. 9.
} 
Gambar 1. Model Perilaku Konsumen

\begin{tabular}{|c|c|c|}
\hline $\begin{array}{l}\text { Pemasaran dan } \\
\text { stimulasi lainnya } \\
\text { 3auran pemasaran } \\
\text { - } \text { Produk } \\
\text { - Harga } \\
\text { - Distibusi } \\
\text { - Promosi } \\
\text { Lain-lain } \\
\text { - } \quad \text { Ekonomi } \\
\text { - Teknologi } \\
\text { - Politik } \\
\text { - Budaya }\end{array}$ & $\begin{array}{l}\text { Buyer's Black Box } \\
\text { Karakteristik } \\
\text { Pembeli }\end{array}$ & $\begin{array}{l}\text { Respon Pembeli } \\
\text { Pemilihan produk } \\
\text { Pemilihan merek } \\
\text { Pemilihan saluran }\end{array}$ \\
\hline
\end{tabular}

Sumber: M. Taufiq Amin. Dinamika Pemasaran. 2005. hlm. 28.

Dalam Islam, perilaku seorang konsumen harus mencerminkan hubungan dirinya dengan Allah Swt. Inilah yang tidak kita dapati dalam ilmu perilaku konsumensi kovensional. Setiap pergerakan dirinya, yang berbentuk belanja sehari-hari, tidak lain adalah manifestasi zikir dirinya atas nama Allah. Dengan demikian, dia lebih memilih jalan yang dibatasi Allah dengan tidak memilih barang haram, tidak kikir, dan tidak tamak supaya hidupnya selamat baik di dunia maupun di akhirat. ${ }^{10}$

Kemudian, yang tidak kita dapati pada kajian perilaku konsumsi dalam perspektif ilmu ekonomi konvensional adalah kehadiran saluran penyeimbang dari saluran kebutuhan individual yang disebut dengan saluran konsumsi sosial. Saluran ini hanya ada dalam ekonomi Islam. Alquran berulang kali mengajarkan umat Islam agar menyalurkan sebagian hartanya dalam bentuk zakat, sedekah dan infaq. Tak lain dari muatan ajaran tersebut bahwa pada sesungguhnya umat Islam yang lainnya. Mereka diibaratkan satu organ tubuh. Bila ada yang sakit, organ tubuh lainnya akan merasa sakit pula. Demikian pula jika kita kiaskan dengan kiaskan dengan penderitaan seorang Muslim karena kemiskinan dan kefakiran, sudah seharusnya umar Islam yang lain, terutama yang mampu, dan rupanya jumlah mereka tidak sedikit, merasakan pula aoa yang diderita saudaranya. ${ }^{11}$

Batasan konsumsi dalam syariah adalah pelarangan israf atau berlebih-lebihan. Perilaku israf diharamkan sekalipun komoditi yang dibelanjakan adalah halal. Namun demikian,Islam tetap memperbolehkan seorang muslim untuk menikmati karunia

\footnotetext{
${ }^{10}$ Muhammad Muflih, Perilaku Konsumen dalam Perspektif Ilmu Ekonomi Islam (Jakarta: PT. Raja Grafindo Persada, 2006), hlm. 4.

${ }^{11}$ Ibid., hlm. 6.
} 
kehidupan selama masih dalam batas kewajaran. ${ }^{12}$ sebagaimana dijelaskan Allah dalam Q.S Al-A'raf / 7: 31.

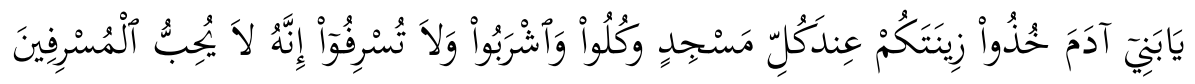

Artinya: "Hai anak Adam, pakailah pakaianmu yang indah di Setiap (memasuki) mesjid, Makan dan minumlah, dan janganlah berlebih-lebihan. Sesungguhnya Allah tidak menyukai orang-orang yang berlebih-lebihan"13

Arti penting yang dapat dipelajari dari ayat di atas adalah kenyataan bahwa kebutuhan hidup itu harus terpenuhi secara wajar agar kelangsungan hidup berjalan dengan baik. Namun, bila kebutuhan hidup itu dipenuhi dengan cara yang berlebihlebihan tentu akan menimbulkan efek buruk pada manusia tersebut. Banyak sekali efek buruk yang ditimbulkan karena israf diantaranya adalah inefiesensi pemanfaatan sumber daya, egoisme, self-interest, dan tunduknya diri terhadap hawa nafsu sehingga uang yang dibelanjakan hanya habis untuk dibelanjakan hal-hal yang tidak perlu dan merugikan diri. ${ }^{14}$

Berikut ini beberapa faktor-faktor penyebab munculnya perilaku konsumen yaitu:

1. Harga

Dalam teori ekonomi, harga, nilai, dan faedah merupakan istilah-istilah yang saling berhubungan. Faedah adalah atribut suatu barang yang dapat memuaskan kebutuhan sedangkan nilai adalah ungkapan secara kuantitatif tentang kekuatan barang untuk dapat menarik barang lain dalam pertukaran. Tetapi perekonomian kita bukan sistem barter, maka untuk mengadakan pertukaran atau untuk mengukur nilai suatu barang kita menggunakan uang dan istilah yang dipakai adalah harga. Jadi harga adalah nilai yang dinyatakan dalam rupiah. ${ }^{15}$ Harga adalah nilai yang dapat menghasilkan pendapatan berupa sejumlah uang yang harus dibayarkan pada produk atau jasa tertentu apabila harga lebih tinggi dari nilai tersebut maka pertukaran tidak akan terjadi. Beberapa faktor yang mencirikan indikator harga yaitu: ${ }^{16}$

a. Keterjangkauan Harga

Adalah harga sesungguhnya dari suatu produk yang tertulis di produk yang akan dibeli konsumen dan harus dibayarkan. Maksudnya adalah konsumen cenderung melihat harga akhir dan memutuskan apakah akan menerima

\footnotetext{
${ }^{12}$ Ibid., hlm. 15.

${ }^{13}$ Departemen Agama RI, op.cit, hlm. 225.

${ }^{14}$ Ibid., hlm. 16.

${ }^{15}$ Basu Swastha, Azas-Azas Marketing Edisi 3 (Yogyakarta: Liberty Yogyakarta, 1999), hlm. 147.

${ }^{16}$ Fauzi Al-Hafiz, "Pengaruh Harga dan Inovasi Produk terhadap Keputusan Pembelian pada Pondok Lesehan Madukoro Bakso Mataram di Jalan Tamir Hamzah Medan" (Skripsi ini tidak diterbitkan, Fakultas Ekonomi dan Bisnis, Universitas Sumatera Utara, Medan, 2016), hlm. 11-14. http://repository.usu.ac.id/bitstream/123456789/63729/7. (12 September 2017).
} 
nilai yang baik seperti yang diharapkan. Harapan pelanggan dalam melihat harga yaitu:

1) Harga yang ditawarkan mampu dijaga oleh pelanggan secara finansial

2) Penentuan harga harus sesuai dengan kualitas produk sehingga pelanggan dapat mempertimbangkan dalam melakukan pembelian.

b. Diskon

Umumnya masyarakat menyukai diskon karna dengan adanya diskon ini akan lebih murah dalam berbelanja. Diskon adalah pengurangan dari harga yang diberikan oleh penjual kepada pembeli yang menyerahkan sejumlah fungsi pemasaran atau menyediakan sendiri fungsi tersebut. ${ }^{17}$

c. Kesesuaian harga dengan kualitas produk

Harga termasuk bagian dari jual beli, jual beli sendiri adalah proses pemindahan hak milik/barang atau harta kepada pihak lain dengan menggunakan uang sebagai alat tukarnya. Apabila harga tidak disesuaikan kualitas produk dengan tujuan mencari keuntungan bagi pihak produsen atas harta konsumen, maka hal tersebut akan bertentangan dengan ajaran Islam ${ }^{18}$ sebagaimana dijelaskan Allah dalam Q.S An-Nisa / 4: 29.

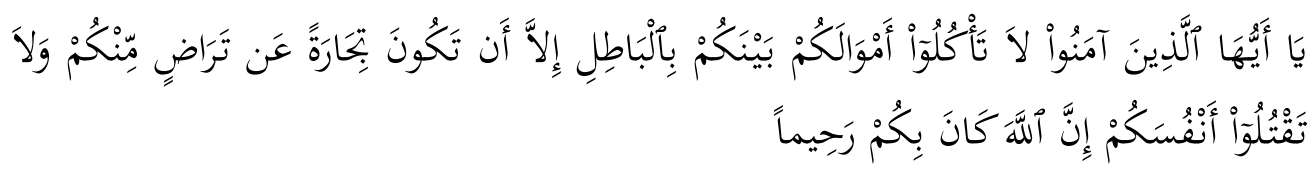

Artinya: "Hai orang-orang yang beriman, janganlah kamu saling memakan harta sesamamu dengan jalan yang batil, kecuali dengan jalan perniagaan yang Berlaku dengan suka sama-suka di antara kamu. dan janganlah kamu membunuh dirimu; Sesungguhnya Allah adalah Maha Penyayang kepadamu". ${ }^{19}$

d. Daya saing harga

Harga jual beberapa macam barang sering dipengaruhi oleh keadaan pesaing yang ada. Barang-barang dari hasil pertanian misalnya, dijual dalam keadaan persaingan murni (pure competition). Dalam persaingan seperti ini penjual yang berjumlah banyak aktif menghadapi pembeli yang banyak pula. Banyaknya penjual dan pembeli ini akan mempersulit penjual perorangan untuk menjual dengan harga lebih tinggi kepada pembeli yang lain. Selain persaingan murni, dapat pula terjadi keadaan persaingan lainnya, seperti persaingan tidak sempurna, oligopoli, dan monopoli. ${ }^{20}$

\footnotetext{
${ }^{17}$ Canon, Perreault, dan McCarthy, Pemasaran Dasar Pendekatan Manajerial Global, terj. Diana Angelica (Jakarta: Salemba Empat, 2009), hlm. 192.

${ }^{18}$ Hetti Sri Wardani, "Pengaruh Kualitas Produk dan Harga terhadap Minat Beli Konsumen Muslim pada Jaizah Boutique Tlogosari Semarang" (Skripsi tidak diterbitkan, Fakultas Ekonomi dan Bisnis Islam, Universitas Islam Negeri Walisongo, Semarang, 2015), hlm. 27. http://eprints.walisongo.ac.id/5457. (2 September 2017).
}

${ }^{19}$ Departemen Agama RI, op.cit, hlm. 122.

${ }^{20}$ Basu Swastha, Pengantar Bisnis Modern (Yogyakarta: Liberty Yogyakarta, 2000), hlm. 214. 
e. Kesesuaian harga dengan manfaat

Konsumen memutuskan membeli suatu produk jika manfaat yang dirasakan lebih besar atau sama dengan yang telah dikeluarkan untuk mendapatkannya. Jika konsumen merasakan manfaat produk lebih kecil dari uang yang dikeluarkan, maka konsumen akan beranggapan bahwa produk tersebut mahal dan konsumen akan berpikir dua kali untuk melakukan pembelian ulang.

Apabila harga sebuah barang yang dibeli oleh konsumen dapat memberikan hasil yang memuaskan, maka dapat dikatakan bahwa penjualan total perusahaan akan berada pada tingkat yang memuaskan, diukur dalam nilai rupiah sehingga dapat menciptakan langganan. ${ }^{21}$

2. Tren

Ini satu lagi yang dapat mempengaruhi secara tidak langsung, tetapi dapat menentukan kelangsungan pemasaran perusahaan. Ada kecenderungankecenderungan yang harus "dibaca" oleh orang pemasaran. Untuk itu, cara melihat yang kreatif dibutuhkan di sini. Kecenderungan-kecenderungan baru adalah tren yang anda lihat dalam kehidupan sehari-hari misalnya ketika Inul Darasista menghentakkan dunia hiburan dengan goyangannya. Jika anda ingat, pada saat awal ia tampil di Live TV, acara-acaranya mampu malam Jakarta lebih cepat sepi. Masyarakat ingin lebih cepat sampai rumah untuk menyaksikannya. Para pelaku bisnis terkait langsung memanfaatkannya dengan membuat acaraacara dangdut, membuat sinetron dangdut, lomba dangdut dan sebagainya. ${ }^{22}$ Beberapa faktor yang mencirikan indikator tren, sebagai berikut:

a. Perkembangan zaman

b. Mengikuti fasion terbaru

c. Pergaulan

d. Ingin tampil beda

3. Religiusitas

Menurut Glock dan Stark mengemukakan ada lima dimensi yang dapat dijadikan objek dalam penelitian tentang religiusitas yaitu: ${ }^{23}$

a. Keyakinan. Dimensi ini berkenaan dengan pandangan teologis dan pengakuan terhadap doktrin-doktrin mengenai keyakinan kepada Tuhan. Misalnya kepercayaan kepada Tuhan, malaikat, surga dan neraka. Sebagaimana Rasulullah Shallallahu 'alaihiwasallam bersabda:

\footnotetext{
${ }^{21}$ Basu Swastha, op.cit. hlm. 148.

${ }^{22}$ M. Taufiq Amir, op.cit, hlm. 36.

${ }^{23}$ Imam Suprayoga dan Tobroni, Metodologi Penelitian Sosial-Agama (Bandung: PT Remaja Rosdakarya, 2003), hlm. 21-22.
} 


$$
\begin{aligned}
& \text { عمر بن الخطاب رضي الله عنهما قال : سمعت النبي صلَّى الله عليه وسلَّم يقول : بُنيَ الْإِسنَلَمُ }
\end{aligned}
$$

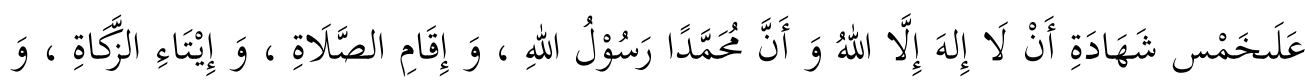

$$
\begin{aligned}
& \text { حَبْ الْبَيْتِ ،وَ صَوْمر رَمَضَانَ .رواه البخاري } 24
\end{aligned}
$$

Artinya: Dari Umar bin Al-Khaththab radhiyallahu 'anhuma-, katanya, Aku mendengar Nabi Shallallahu'alaihi Wasallam bersabda, "Islam dibangun di atas lima: persaksian bahwa tidak ada tuhan yang berhak disembah dengan benar kecuali Allah dan Muhammad adalah utusan Allah, mendirikan shalat, menunaikan zakat, naik haji, dan puasa Ramadhan". (HR. Bukhari)

b. Praktik Agama. Dimensi ini mencakup perilaku pemujaan, pelaksanaan ritus formal keagamaan, ketaatan, dan hal-hal yang dilakukan orang untuk menunjukkan komitmen terhadap agama yang dianutnya. Dalam Islam dimensi praktik agama ini seperti salat, puasa, haji, doa, wiridan, pembacaan ayat suci Alquran, perkawinan, dan khitan. Sebagaimana diatur oleh sabda Nabi

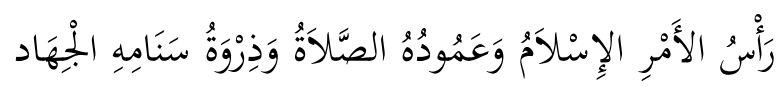

Artinya: "Pokok perkara adalah Islam, tiangnya adalah shalat, dan puncak perkaranya adalah jihad" (HR. Tirmidz/i). ${ }^{25}$

c. Pengalaman Agama. Dimensi ini berkaitan dengan pengalaman keagamaan, perasaan-perasaan, persepsi-persepsi, dan sensasi-sensasi yang dialami seseorang atau sekelompok orang ketika berkomunikasi dengan zat yang supranatural. Menurut Jalaludin Rakhmat membagi pengalaman keagamaan dalam dunia sufi pada empat tinadirgkatan: konfirmatif (merasakan kehadiran Tuhan atau apa saja yang diamatinya), responsif (merasa bahwa Tuhan menjawab kehendaknya atau keluhannya), eskatif (merasakan hubungan yang akrab dan penuh cinta dengan Tuhan), partisipatif (merasa menjadi kawan setia kekasih atau wali Tuhan dan menyertai Tuhan dalam melakukan karya ilahiah).

d. Pengetahuan Agama. Dimensi ini berkenaan dengan tingkat pengetahuan penganut agama terhadap doktrin teoritis, ritus-ritus, kitab suci, dan tradisitradisi atau kultur keberagamaan.

e. Pengalaman. Dimensi ini berkenaan dengan identifikasi akibat-akibat keyakinan keagamaan, praktek, pengalaman dan pengetahuan keagamaan seseorang dalam kehidupan sehari-hari. Merujuk pada seberapa tinggi tingkatan seorang muslim berprilaku dimotivasi oleh ajaran-ajaran agamanya. Akhlak sebenarnya adalah buah dari keyakinan dan ibadah seseorang. Akhlak merupakan fungsionalisasi agama, artinya keberagamaan

\footnotetext{
${ }^{24}$ Muhammad bin Ismail, ShahihBukhari (Beirut DarulFiqri) Juz IX, Bab Ikrah, hlm. 2.

${ }^{25} \mathrm{Abi}$ Isa Muhammad bin Isa bin Saurah, Sunan At- Tirmidz/i (Beirut: DarulFiqri, 1988), hlm. 299.
} 
menjadi tidak berarti bila tidak dibuktikan dengan berakhlak. Misalnya suka menolong, bekerjasama, menegakkan keadilan dan kebenaran, berkata jujur, memaafkan, menjaga lingkungan hidup dan sebagainya. Sebagaimana dijelaskan Allah dalam Q.S Saba' / 34: 37.

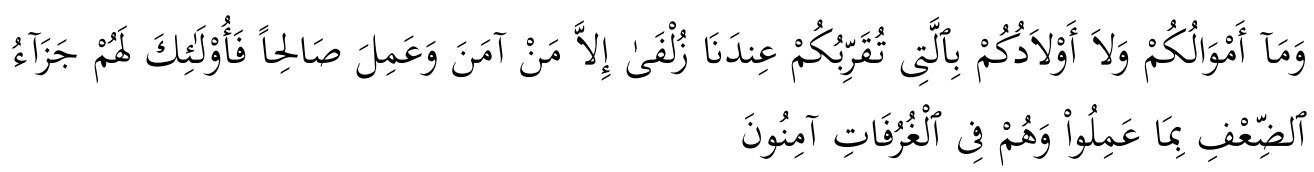

Artinya: "Dan sekali-kali bukanlah harta dan bukan (pula) anak-anak kamu yang mendekatkan kamu kepada Kami sedikitpun; tetapi orangorang yang beriman dan mengerjakan amal-amal saleh, mereka itulah yang memperoleh balasan yang berlipat ganda disebabkan apa yang telah mereka kerjakan; dan mereka aman sentosa di tempat-tempat yang tinggi (dalam syurga)." 26

4. Minat Beli

Dalam Alquran berbicara tentang minat terdapat surah pertama turun. Pada ayat pertama dari surah pertama turun perintahnya adalah agar kita membaca. Membaca yang dimaksud bukan hanya membaca buku atau dalam artian tekstual, akan tetapi juga semua aspek. Apakah itu tuntunan untuk membaca cakrawala jagat yang merupakan tanda kebesaran-Nya, serta membaca potensi diri, sehingga dengannya kita dapat memahami apa yang sebenarnya hal yang menarik minat kita dalam kehidupan ini. ${ }^{27}$ Sebagaimana Allah berfirman dalam Q.S. al 'Alaq / 96: 3-5.

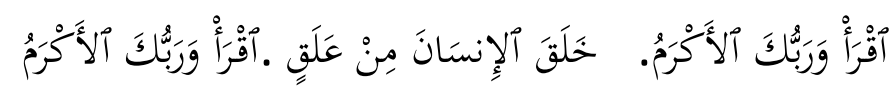

Artinya: "Bacalah, dan Tuhanmulah yang Maha pemurah. Yang mengajar (manusia) dengan perantaran kalam. Dia mengajar kepada manusia apa yang tidak diketahuinya" 28

Secara sederhana minat dapat diartikan sebagai suatu kecenderungan untuk memberikan perhatian dan tindakan terhadap orang, aktivitas, atau situasi yang menjadi objek dari minat tersebut dengan disertai perasaan senang. Dalam batasan tersebut di dalam minat ada pemusatan perhatian subjek, ada usaha (untuk mengetahui/mendekati/memiliki/menguasai/ berhubungan) dari subjek yang dilakukan ada perasaan senang, ada daya penarik dari objek. ${ }^{29}$

Dalam kaitannya dengan pembelian, seorang konsumen harus mempunyai keinginan terhadap produk terlebih dahulu sebelum memutuskan untuk membeli produk tersebut. Minat beli merupakan bagian dari komponen perilaku

\footnotetext{
${ }^{26}$ Departemen Agama RI, op, cit., hlm. 689.

${ }^{27} \mathrm{Abdul}$ Rahman Shaleh dan Muhbib Abdul Wahab, op.cit, hlm. 273.

${ }^{28}$ Departemen Agama RI, op.cit, hlm. 1079.

${ }^{29}$ Abdul Rahman Shaleh dan Muhbib Abdul Wahab, op. cit, hlm. 263.
} 
dalam sikap mengkonsumsi. Minat beli adalah tahap kecenderungan responden untuk bertindak sebelum keputusan membeli benar-benar dilaksanakan. Konsumen mungkin juga membentuk pembelian untuk membeli merek yang paling disukai. Meski demikian, ada dua faktor yang berintervensi diantara minat pembelian dan keputusan pembelian. Faktor-faktor ini ditunjukkan dalam gambar dibawah ini: ${ }^{30}$

Gambar 2. Tahap-tahap di antara Evaluasi Alternatif

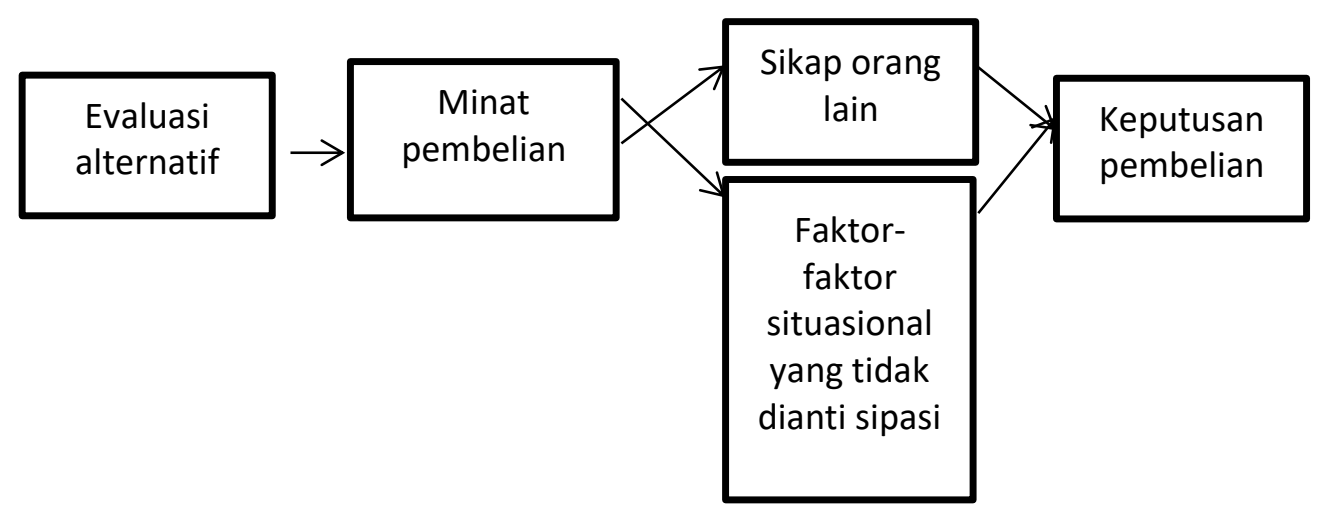

Sumber: Philip Kotler. Manajemen Pemasaran. 1996. hlm. 256.

\section{Metode Penelitian}

\subsection{Jenis dan Pendekatan Penelitian}

Jenis penelitian yang digunakan adalah penelitian survei (survey research) yaitu penelitian yang tidak melakukan perubahan (tidak ada perlakuan khusus) terhadap variabel-variabel yang diteliti. ${ }^{31}$ Digunakan untuk mendapatkan data dari tempat alamiah (bukan buatan) tetapi peneliti melakukan perlakuan dalam pengumpulan data misalnya mengedarkan kuesioner. $^{32}$ Ada pun pendekatan penelitian ini menggunakan pendekatan kuantitatif.

\subsection{Populasi dan Sampel}

Populasi adalah wilayah generalisasi yang terdiri atas subjek dan objek yang mempunyai kualitas dan karakteristik tertentu yang ditetapkan oleh peneliti untuk dipelajari kemudian ditarik kesimpulannya. ${ }^{33}$ Populasi yang dimaksud adalah seluruh mahasiswi UIN Antasari Banjarmasin yang berstatus aktif sebagai mahasiswi. Jumlah populasi mahasiswi UIN Antasari Banjarmasin sebanyak 4.330. ${ }^{34}$

\footnotetext{
${ }^{30}$ Philip Kotler, Manajemen Pemasaran Persepektif Asia, op.cit, hlm. 256.

${ }^{31}$ Syofian Siregar, Statistik Parameter untuk Penelitian Kuantitatif (Jakarta: PT Bumi Aksara, 2012), hlm. 10.

${ }^{32}$ Sugiyono, op. cit., hlm 12.

${ }^{33}$ Ibid., hlm. 117.

${ }^{34}$ Sumber dari Kabag Akademik, Kemahasiswaan dan Alumni UIN Antasari Banjarmasin.
} 
Sampel adalah bagian dari jumlah dan karakteristik yang dimiliki oleh populasi tersebut. ${ }^{35}$ Adapun metode pengambilan sampel yang digunakan dalam penelitian ini adalah Stratified Sampling Proporsional yaitu jumlah sampel yang diambil dari setiap strata sebanding sesuai dengan proporsi ukurannya. ${ }^{36}$ Maksudnya peneliti mengambil sampel melihat pada tingkatan yang akan diambil jadi ada jumlah responden tertentu untuk kuesioner yang akan dibagi pada 4 Fakultas agar pengambilan dalam jumlah populasi yang banyak tersebut bisa terwakilkan semuanya. Menentukan sampel dari populasi yang didapat kita bisa menggunakan rumus solvin yaitu: ${ }^{37}$

$$
n=\frac{N}{1+\left(N \times e^{2}\right)}
$$

Keterangan:

$\mathrm{n}=\quad$ Ukuran sampel

$\mathrm{N} \quad=$ Populasi

e = Persentasi kelonggaran ketidakterikatann karena kesalahan pengambilan sampel yang masih di inginkan

Diketahui jumlah populasi mahasiswi UIN Antasari Banjarmasin yang berstatus aktif kuliah sebanyak 4.330 dan persentasi kelonggaran yang ditetapkan sebesar $5 \%$. Maksudnya dalam persentasi $5 \%$ peneliti bisa mendapatkan jumlah responden yang banyak sehingga sampel yang di dapat akurat karena semakin banyak sampel yang diambil, maka akan semakin repsentatif (terwakili) ${ }^{38}$. Berikut perhitungannya:

$$
\begin{gathered}
n=\frac{4330}{1+\left(4330 \times 5 \%^{2}\right)} \\
n=\frac{4330}{1+(4330 \times 0,0025)} \\
n=\frac{4330}{1+10,825} \\
n=\frac{4330}{11,825} \\
n=366,17 \\
n=366
\end{gathered}
$$

\footnotetext{
${ }^{35}$ Sugiyono, op. cit., hlm 118.

${ }^{36}$ Syofian Siregar, op.cit., hlm. 57.

${ }^{37}$ V. Wiranta Sujarweni dan Poly Endrayanto, Statistik Untuk Penelitian (Yogyakarta: Graha IImu, 2012), hlm. 17.

${ }^{38}$ Nur Asnawi dan Masyhuri, Metodelogi Riset Manajemen Pemasaran (Malang: UIN Maliki Press, 2011), hlm. 142.
} 
Jadi jumlah sampel yang akan di teliti sebesar 366 responden maka peneliti membagi jumlah sampel tersebut kedalam 4 bagian sesuai Fakultas yang ada di UIN Antasari Banjarmasin dengan rumus sebagai berikut: ${ }^{39}$

$$
n_{i}=\frac{N_{i}}{N \cdot n}
$$

Keterangan :

$\mathrm{n}_{\mathrm{i}}=\quad$ Jumlah sampel menurut stratum

$\mathrm{n} \quad=\quad$ Jumlah sampel seluruhnya

$\mathrm{N}_{\mathrm{i}}=$ Jumlah populasi menurut stratum

$\mathrm{N}=$ Jumlah populasi seluruhnya

Adapun perhitungan pembagian sampel menurut stratum atau tingkatannya yaitu:

1) Fakultas Tarbiyah dan Keguruan

$$
\begin{array}{r}
n_{i}=\frac{2509}{4330.366} \\
n_{i}=212,07=212
\end{array}
$$

2) Fakultas Syariah dan Ekonomi Islam

$$
\begin{gathered}
n_{i}=\frac{1308}{4330.366} \\
n_{i}=110,56=111
\end{gathered}
$$

3) Fakultas Ushuludin dan Humaniora

$$
\begin{aligned}
& n_{i}=\frac{307}{4330.366} \\
& n_{i}=25,94=26
\end{aligned}
$$

4) Fakultas Dakwah dan Komunikasi

$$
\begin{aligned}
& n_{i}=\frac{206}{4330.366} \\
& n_{i}=17,41=17
\end{aligned}
$$

Seperti perhitungan diatas dari beberapa tingkatannya didapat pada Fakultas Tarbiyah dan Keguruan jumlah stratumnya sebesar 212 responden, Fakultas Syariah dan Ekonomi Islam jumlah stratumnya sebesar 111 responden, Fakultas Ushuludin dan Humaniora jumlah stratumnya sebesar 26 responden dan Fakultas Dakwah dan Komunikasi jumlah stratumnya sebesar 17 responden. Sehingga peneliti akan membagi kuesioner pada jumlah stratum yang telah ditentukan pada perhitungan diatas.

\subsection{Desain Pengukuran dan Instrumen Kuesioner}

Skala Likert adalah skala yang digunakan untuk mengukur sikap, pendapat dan persepsi seseorang tentang suatu objek atau fenomena tertentu. ${ }^{40}$ sehingga penulis

${ }^{39}$ Ibid., hlm. 147 
pada penelitian ini menggunakan metode skala Likert pada pengukuran jawaban responden. Dalam pengukuran skala likert ada lima opsi jawaban sebagai berikut: ${ }^{41}$
a. Sangat setuju (SS)
$=$ diberi skor 5
b. Setuju (S)
$=$ diberi skor 4
c. Kurang Setuju (KS)
$=$ diberi skor 3
d. Tidak setuju (TS)
$=$ diberi skor 2
e. $\quad$ Sangat tidak setuju (STS) $=$ diberi skor 1

Instrumen kuesioner adalah alat yang digunakan untuk mengumpulkan data primer dalam penelitian ini dikembangkan dari variabel penelitian, baik variabel independen maupun variabel dependen, sebagaimana dijelaskan dalam tabel ini:

Table 1. Indikator kuesioner

\begin{tabular}{|c|c|c|}
\hline Variable & Indikator & Skala Pengukuran \\
\hline Harga $\left(X_{1}\right)$ & $\begin{array}{l}\text { 1. Keterjangkauan Harga } \\
\text { 2. Diskon } \\
\text { 3. Kesesuaian harga dengan } \\
\text { kualitas produk } \\
\text { 4. Daya saing harga } \\
\text { 5. Kesesuaian harga dengan } \\
\text { manfaat produk }\end{array}$ & Likert \\
\hline $\operatorname{Tren}\left(X_{2}\right)$ & $\begin{array}{l}\text { 1. Perkembangan zaman } \\
\text { 2. Mengikuti fasion terbaru } \\
\text { 3. Pergaulan } \\
\text { 4. Ingin tampil beda }\end{array}$ & Likert \\
\hline Religiusitas $\left(\mathrm{X}_{3}\right)$ & $\begin{array}{l}\text { 1. Ideologis (Keyakinan) } \\
\text { 2. Ritualistik (Praktik } \\
\text { Keagamaan) } \\
\text { 3. Experensial (Pengalaman } \\
\text { Agama) } \\
\text { 4. Konsekuensi } \\
\text { (Pengalaman) } \\
\text { 5. Intelektual(Pengetahuan } \\
\text { Keagaman) }\end{array}$ & Likert \\
\hline Minat Beli (Y) & $\begin{array}{l}\text { 1. Minat transaksional } \\
\text { 2. Minat refrensial } \\
\text { 3. Minat preferensi } \\
\text { 4. } \text { Minat eksploratif }\end{array}$ & Likert \\
\hline
\end{tabular}

Sumber: Moh. Nazir. Bogor. Metode Penelitian. 2014. hlm. 213

\footnotetext{
${ }^{40}$ Syofian Siregar, op. cit, hlm. 50.

${ }^{41}$ Ibid.,
} 


\subsection{Analisis Data}

\subsubsection{Analisis Regresi Liner Berganda}

Regresi ini memiliki satu variabel dependen $(Y)$ dan dua atau lebih variabel independen (X). ${ }^{42}$ Analisis ini digunakan untuk meramalkan bagaimana keadaan (naik turunnya) nilai dari variabel tergantung (kreterium), bila dua atau lebih variabel bebas (independen) sebagai faktor prediktor dimanipulasi (dinaikturunkan nilai). Berikut adalah rumus regresi linier berganda untuk 3 prediktor: ${ }^{43}$

$$
Y=a+b_{1} X_{1}+b_{2} X_{2}+b_{3} X_{3}
$$

Keterangan:

$\begin{array}{ll}\mathrm{Y} & =\text { Minat Beli } \\ \mathrm{a} & =\text { Konstan } \\ \mathrm{b}_{1}, \mathrm{~b}_{2}, \mathrm{~b}_{3} & =\text { Koefisien Regresi } \\ \mathrm{X}_{1} & =\text { Harga } \\ \mathrm{X}_{2} & =\text { Tren } \\ \mathrm{X}_{3} & =\text { Religiusitas }\end{array}$

\subsubsection{Uji Hipotesis}

1. Analisis Koefisien Determinan $\left(R^{2}\right)$

Analisis determinasi digunakan untuk mengetahui persentasi sumbangan pengaruh variabel bebas secara bersama-sama terhadap tergantung koefisien determinasi menunjukkan seberapa besar persentasi variasi variabel tergantung $\mathrm{R}=0$

2. Uji Koefisien Regresi secara Simultan (uji f)

Uji f digunakan untuk mengetahui apakah kedua variabel tak bebas secara bersama-sama (simultan) mempengaruhi variabel tak bebas. ${ }^{44}$

3. Uji Koefisien secara Parsial (uji t)

Digunakan untuk menguji pengaruh variabel bebas secara parsial terhadap variabel tergantung.

\section{Hasil Penelitian dan Pembahasan}

Untuk menjawab rumusan masalah yang ada dapat kita ketahui melalui analisis regresi liner berganda dan uji hipotesis yaitu:

\footnotetext{
${ }^{42}$ V. Wiranta Sujarweni dan Poly Endrayanto, op. cit, hlm. 88.

${ }^{43}$ Syofian Siregar, op.cit. hlm. 443.

${ }^{44}$ Ibid., hlm. 439
} 


\subsection{Analisis Regresi Liner Berganda}

Untuk mengetahui pengaruh variabel harga $\left(X_{1}\right)$, tren $\left(X_{2}\right)$ dan religiusitas $\left(X_{3}\right)$ terhadap minat beli pakaian syar'i $(\mathrm{Y})$, menggunakan regresi linier berganda dengan persamaan sebagai berikut:

$$
Y=a+b_{1} X_{1}+b_{2} X_{2}+b_{3} X_{3}
$$

Keterangan:

$\begin{array}{ll}\mathrm{Y} & =\text { Minat Beli } \\ \mathrm{a} & =\text { Konstan } \\ \mathrm{b}_{1}, \mathrm{~b}_{2}, \mathrm{~b}_{3} & =\text { Koefisien Regresi } \\ \mathrm{X}_{1} & =\text { Harga } \\ \mathrm{X}_{2} & =\text { Tren } \\ \mathrm{X}_{3} & =\text { Religiusitas }\end{array}$

Tabel 2. Regresi liner berganda

\begin{tabular}{|c|c|c|c|c|c|c|}
\hline & \multirow[b]{2}{*}{ Model } & \multicolumn{2}{|c|}{$\begin{array}{c}\text { Unstandardized } \\
\text { Coefficients }\end{array}$} & \multirow{2}{*}{$\begin{array}{c}\text { Standardized } \\
\text { Coefficients } \\
\text { Beta }\end{array}$} & \multirow[b]{2}{*}{ T } & \multirow[b]{2}{*}{ Sig. } \\
\hline & & B & Std. Error & & & \\
\hline \multirow[t]{4}{*}{1} & (Constant) & 2.432 & 1.087 & & 2.237 & .026 \\
\hline & Harga & .108 & .045 & .104 & 2.402 & .017 \\
\hline & Tren & .146 & .025 & .244 & 5.794 & .000 \\
\hline & Religiusitas & .467 & .040 & .503 & 11.625 & .000 \\
\hline
\end{tabular}

Sumber: Hasil Olah Data SPSS 22 (2017)

Berdasarkan tabel 4.30 di atas diketahui persamaan regresi linier berganda yaitu $\mathrm{Y}=$ $2,432+0,108 \times 1+0,146 \times 2+0,467 \times 3$.

a. Konstanta

Nilai konstanta yang diperoleh sebesar 2,432 menyatakan bahwa jika tidak ada perubahan nilai dari variabel harga $\left(X_{1}\right)$, tren $\left(X_{2}\right)$ dan religiusitas $\left(X_{3}\right)$ maka nilai minat beli pakaian syar'i $(\mathrm{Y})$ adalah sebesar 2,432.

b. Harga $\left(X_{1}\right)$

Nilai koefisien regresi $X_{1}$ sebesar 0,108 dan tanda positif tersebut menunjukan hubungan yang searah. Hal ini berarti, bahwa setiap kenaikan faktor harga satu satuan maka minat beli pakaian syar'i $(\mathrm{Y})$ akan naik 0,108 dengan asumsi bahwa variabel bebas yang lain dari model regresi tetap.

c. $\operatorname{Tren}\left(\mathrm{X}_{2}\right)$

Nilai koefisien regresi $X_{2}$ sebesar 0,146 dan tanda positif tersebut menunjukan hubungan yang searah. Hal ini berarti, bahwa setiap kenaikan faktor tren satu 
satuan maka minat beli pakaian syar'i $(\mathrm{Y})$ akan naik 0,146 dengan asumsi bahwa variabel bebas yang lain dari model regresi tetap.

d. Religiusitas $\left(\mathrm{X}_{3}\right)$

Nilai koefisien regresi $X_{3}$ sebesar 0,467 dan tanda positif tersebut menunjukan hubungan yang searah. Hal ini berarti, bahwa setiap kenaikan faktor religiusitas satu satuan maka minat beli pakaian syar'i (Y) akan naik 0,467 dengan asumsi bahwa variabel bebas yang lain dari model regresi tetap.

\subsection{Uji Hipotesis}

Untuk mengetahui pengaruh antar variabel harga, tren dan religiusitas maka dilakukan pengujian-pengujian yaitu uji determinasi, uji $F$ (uji simultan) dan uji t (uji signifikan parsial).

a. Hasil Uji Koefisien Determinasi

Koefisien determinasi bertujuan untuk mengukur proporsi variasi dalam variabel tidak bebas yang dijelaskan oleh regresi. Nilai $R^{2}$ berkisar antara 0 sampai 1 , jika $R^{2}=0$ berarti tidak ada hubungan yang sempurna. Sedangkan apabila $R^{2}=1$ maka ada hubungan antara variasi $\mathrm{Y}$ dan $\mathrm{X}$ atau variasi dari $\mathrm{Y}$ dapat diterangkan oleh $\mathrm{X}$ secara keseluruhan.

Tabel 3. Hasil Uji Koefisien Determinasi

\begin{tabular}{crrrr}
\hline Model & $\mathrm{R}$ & R Square & $\begin{array}{c}\text { Adjusted } \\
\text { Square }\end{array}$ & $\begin{array}{r}\text { Std. Error of } \\
\text { the Estimate }\end{array}$ \\
\hline 1 &, $600^{\mathrm{a}}$ &, 360 &, 355 & 1,703
\end{tabular}

Sumber: Hasil Olah Data SPSS 22 (2017)

Berdasarkan tabel 4.31 di atas, nilai adjusted $\mathrm{R}^{2}$ dalam penelitian ini adalah sebesar 0,355. Hal ini menunjukan bahwa besar pengaruh variabel independent yaitu harga, tren dan religiusitas terhadap variabel dependent yaitu minat beli pakaian syar'i yang dapat diterangkan oleh model persamaan ini sebesar 35,50\% sedangkan sisanya $64,50 \%$ dipengaruhi oleh faktor lain di luar penelitian.

b. Uji F (Uji Simultan)

Untuk mengetahui pakan variabel harga, tren dan religiusitas yang dimasukkan dalam model re gresi mempunyai pengaruh signifikan secara simultan terhadap variabel minat beli pakaian syar'i maka dilakukan uji $\mathrm{F}$.

Tabel 4. Hasil Uji F

\begin{tabular}{llrrrrr}
\hline \multirow{2}{*}{ Model } & $\begin{array}{l}\text { Sum of } \\
\text { Squares }\end{array}$ & Df & $\begin{array}{l}\text { Mean } \\
\text { Square }\end{array}$ & \multicolumn{1}{c}{$F$} & Sig. \\
\hline 1 & Regression & 590,453 & 3 & 196,818 & 67,900 &, $000^{\text {b }}$ \\
\cline { 2 - 7 } & Residual & 1049,306 & 362 & 2,899 & & \\
\cline { 2 - 7 } & 1639,760 & 365 & & & \\
\hline
\end{tabular}


Sumber: Hasil Olah Data SPSS 22 (2017)

Berdasarkan tabel 4.32 diatas nilai Fhitung sebesar 67,900 di mana nilai ini lebih besar dari nilai $F_{\text {tabel }}$ sebesar $1,19(67,900>1,19)$ dan nilai signifikan $F$ sebesar 0,000 , dimana nilai ini lebih kecil dari nilai a sebesar 0,05 $(0,000<0,05)$. Hal ini menunjukan bahwa secara bersama-sama faktor harga, tren dan religiusitas berpengaruh secara signifikan terhadap minat beli pakaian syar'i pada mahasiswi UIN Antasari Banjarmasin.

c. Uji t (Uji Parsial)

Uji t digunakan untuk memprediksi ada tidaknya pengaruh secara parsial variabel independent terhadap variabel dependent. Jika dalam pengujian dipastikan bahwa koefisien regresi suatu variabel independent tidak sama dengan nol, maka variabel independent tersebut berpengaruh terhadap variabel dependent. Sebaliknya, jika dalam pengujian tersebut dipastikan bahwa koefisisen regresi suatu variable independent sama dengan nol, maka variabel independent tersebut tidak berpengaruh terhadap variabel dependent.

Tabel 5. Hasil Uji t

\begin{tabular}{|c|c|c|c|c|c|c|}
\hline & \multirow[b]{2}{*}{ Model } & \multicolumn{2}{|c|}{$\begin{array}{c}\text { Unstandardized } \\
\text { Coefficients }\end{array}$} & \multirow{2}{*}{$\begin{array}{c}\text { Standardized } \\
\text { Coefficients } \\
\text { Beta }\end{array}$} & \multirow[b]{2}{*}{ T } & \multirow[b]{2}{*}{ Sig. } \\
\hline & & B & Std. Error & & & \\
\hline \multirow[t]{4}{*}{1} & (Constant) & 2,432 & 1,087 & & 2,237 & ,026 \\
\hline & Harga & 108 & ,045 & 104 & 2,402 & ,017 \\
\hline & Tren & 146 & ,025 & 244 & 5,794 & ,000 \\
\hline & Religiusitas & ,467 & ,040 & ,503 & 11,625 & ,000 \\
\hline
\end{tabular}

Sumber: Hasil Olah Data SPSS 22 (2017)

Tabel 5 di atas menunjukkan hasil uji $t$ yang bertujuan menguji pengaruh variabel independent, yaitu harga, tren dan religiusitas. Diperoleh nilai $t$-tabel sebesar 1,97. Berdasarkan hasil uji t diatas, maka ditarik kasimpulan:

1) Harga

Hasil uji t dalam tabel di atas menunjukkan nilai koefisien bernilai positif dan variabel harga diperoleh $t$-hitung sebesar 2,402 lebih besar dari t-tabel sebesar 1,97 dengan tingkat signifikansi 0,017 lebih kecil dari 0,05. Maka berdasarkan hal tersebut variabel harga berpengaruh secara parsial terhadap minat beli pakaian syar'i pada mahasiswi UIN Antasari Banjarmasin

2) Tren

Hasil uji t dalam tabel di atas menunjukkan nilai koefisien bernilai positif dan variabel tren diperoleh $t$-hitung sebesar 5,794 lebih besar dari $t$-tabel sebesar 1,97 dengan tingkat signifikansi 0,000 lebih kecil dari 0,05. Maka 
berdasarkan hal tersebut variabel tren berpengaruh secara parsial terhadap minat beli pakaian syar'i pada mahasiswi UIN Antasari Banjarmasin

3) Religiusitas

Hasil uji t dalam tabel di atas menunjukkan nilai koefisien bernilai positif dan variabel religiusitas diperoleh $\mathrm{t}$-hitung sebesar 11,625 lebih besar dari $\mathrm{t}$-tabel sebesar 1,97 dengan tingkat signifikansi 0,000 lebih kecil dari 0,05. Maka berdasarkan hal tersebut variabel religiusitas berpengaruh secara parsial terhadap minat beli pakaian syar'i pada mahasiswi UIN Antasari Banjarmasin

4) Uji Variabel Dominan

Dalam hipotesis yang diajukan peneliti diantara variabel harga, tren dan religiusitas salah satunya ada yang paling dominan. Dengan hasil uji t dari perbandingan ketiga variabel yaitu variabel harga, tren dan religiusitas. Maka diketahui variabel religiusitas yang paling dominan berpengaruh terhadap minat beli pakaian syar'i pada mahasiswi UIN Antasari Banjarmasin dapat dilihat dari angka unstandardized coefficients sebesar 0,467 serta standardized coefficients sebesar 0,503 serta taraf sig sebesar 0,000 .

\section{Penutup}

\subsection{Kesimpulan}

Dari pembahasan yang telah diuraikan dapat ditarik kesimpulan sebagai berikut:

1. Variabel bebas dalam penelitian ini terdiri dari harga $\left(X_{1}\right)$, tren $\left(X_{2}\right)$ dan religiusitas $\left(X_{3}\right)$ secara simultan berpengaruh terhadap minat beli pakaian syar' $i$ pada mahasiswi UIN Antasari Banjarmasin. Hal ini dapat dilihat dari hasil uji F di mana nilai F-hitung $>$ F-tabel $(67,900>1,19)$ dan nilai signifikan $F$ sebesar 0,000 , di mana nilai ini lebih kecil dari nilai $\alpha$ sebesar $0,05(0,000<0,05)$ sedangkan secara parsial ketiga variabel tersebut berpengaruh terhadap minat beli pakaian syar'i pada mahasiswi UIN Antasari Banjarmasin yaitu variabel harga $\left(X_{1}\right)$ yang dapat dilihat dari hasil uji t dimana nilai t-hitung sebesar 2,402 lebih besar dari t-tabel sebesar 1,97 dan tingkat signifikansi 0,017 lebih kecil dari 0,05, variabel tren $\left(X_{2}\right)$ dengan nilai hitung $t$-hitung sebesar 5,794 lebih besar dari $t$-tabel sebesar 1,97 dengan tingkat signifikansi 0,000 lebih kecil dari 0,05 dan variabel religiusitas dengan nilai hitung $\mathrm{t}$-hitung sebesar 11,625 lebih besar dari $\mathrm{t}$-tabel sebesar 1,97 dengan tingkat signifikansi 0,000 lebih kecil dari 0,05.

2. Variabel religiusitas merupakan variabel yang paling dominan dalam mempengaruhi minat beli pakaian syar'i pada mahasiswi UIN Antasari Banjarmasin. Hal ini dibuktikan dari angka unstandardized coefficients sebesar 0,467 serta standardized coefficients sebesar 0,503 serta taraf sig sebesar 0,000 merupakan angka terbesar dibandingkan variabel harga dan variabel tren. 


\subsection{Saran}

1. Sesuai dengan analisis data maka disarankan kepada konsumen terutama mahasiswi untuk lebih mengetahui guna religiusitas dalam berpakaian syar'i. Seperti yang diketahui religiusitas menjadi faktor yang dominan dalam berpakaian syar'i. Diharapkan mahasiswin UIN Antasari memahami dan mengerti arti religiusitas dalam berpakaian syar'i.

2. Penelitian ini hanya meneliti pengaruh harga, tren dan religiusitas terhadap minat beli pakaian syar'i, adapun faktor lain yang mungkin mempengaruhi minat beli tidak diteliti dalam penelitian ini. Disarankan untuk peneliti selanjutnya melakukan penelitian terhadap faktor-faktor lain yang dapat mempengaruhi minat beli pakaian syar'i.

\section{Daftar Pustaka}

Abi Isa Muhammad bin Isa bin Saurah. 1988. Sunan At-Tirmidji Beirut: Darul Fiqri.

Al-Hafiz, Fauzi. 2016. “Pengaruh Harga dan Inovasi Produk terhadap Keputusan Pembelian pada Pondok Lesehan Madukoro Bakso Mataram di Jalan Tamir Hamzah Medan." Skripsi ini tidak diterbitkan, Fakultas Ekonomi dan Bisnis, Universitas Uumatera Utara, Medan. http://repository.usu.ac.id/bitstream/123456789/63729/7. (12 September 2017).

Amir, M. Taufiq. 2015. Dinamika Pemasaran. Jakarta: PT Raja Grafindo Persada.

Asnawi, Nur dan Masyhuri. 2011. Metodelogi Riset Manajemen Pemasaran. Malang: UIN Maliki Press.

Canon, Perreault, dan McCarthy. 2009. Pemasaran Dasar Pendekatan Manajerial Global, terj. Diana Angelica. Jakarta: Salemba Empat.

Departemen Agama RI. 1999. Al-Qur'an dan Terjemahannya. Semarang: Asy Syifa.

Istiqomah. 2013. "Motivasi Berjilbab Mahasiswa (Studi Kasus Pada Mahasiwa STAIN Salatiga Semester 1 Dan 7)." Skripsi ini tidak diterbitkan, Fakultas Tarbiyah Sekolah Tinggi Islam Negeri (STAN), Salatiga.

Muhammad bin Ismail, Shahih Bukhari. Juz IX, Bab Ikrah, Beirut: Darul Fiqri.

Muflih, Muhammad. 2006. Perilaku Konsumen dalam Perspektif IImu Ekonomi Islam. Jakarta: PT. Raja Grafindo Persada.

Philip Kotler. 1996. Manajemen Pemasaran Perspektif Asia, terj. Fandy Tjiptong. Yogyakarta: Andi.

Sangadji, Etta Mamang. 2013. Perilaku Konsumen. Yogyakarta: Andi.

Shaleh, Abdul Rahman dan Muhbib Abdul Wahab. 2004. Psikologi Suatu dalam Perspektif Islam. Jakarta: Kencana.

Siregar, Syofian. 2012. Statistik Parameter untuk Penelitian Kuantitatif. Jakarta: PT Bumi Aksara. 
Sugiyono. 2007. Metode Penelitian Administrasi. Cet. K-15. Bandung: CV Alfabeth

Sujarweni, Wiranta dan Poly Endrayanto. 2012. , Statistik Untuk Penelitian. Yogyakarta: Graha IImu.

Sukirno, Sadono. 1994. Pengantar Teori Makroekonomi. Jakarta: PT Raja Grafindo Persada. . 1994. Mikroekonomi Teori Pengantar Edisi Ketiga. Jakarta: PT Raja Grafindo Persada.

Suprayoga, Imam dan Tobroni. 2003. Metodologi Penelitian Sosial-Agama. Bandung: PT Remaja Rosdakarya.

Swastha, Basu. 1999. Azas-Azas Marketing Edisi 3. Yogyakarta: Liberty Yogyakarta.

Rabbani, Abu Fathi. 2014. The Secret of Hijab Stories. Surakarta: Ahad Books.

Yayasan Penyelenggaraan Penterjemah Al-Qur'an. 2010. Al-Qur'an ku Dengan Tajwid Blok Warna: 55 Masterpiece in 1. Jakarta: Lestari Books.

Wardani, Hetti Sri. 2015. "Pengaruh Kualitas Produk dan Harga terhadap Minat Beli Konsumen Muslim pada Jaizah Boutique Tlogosari Semarang." Skripsi tidak diterbitkan, Fakultas Ekonomi dan Bisnis Islam, Universitas Islam Negeri Walisongo, Semarang. http://eprints.walisongo.ac.id/5457. (2 September 2017).

Wawancara dengan Ibu Dianah (pemilik toko hijab syari dan gaul), tanggal 08.06.2017, di Pasar Kuripan. 